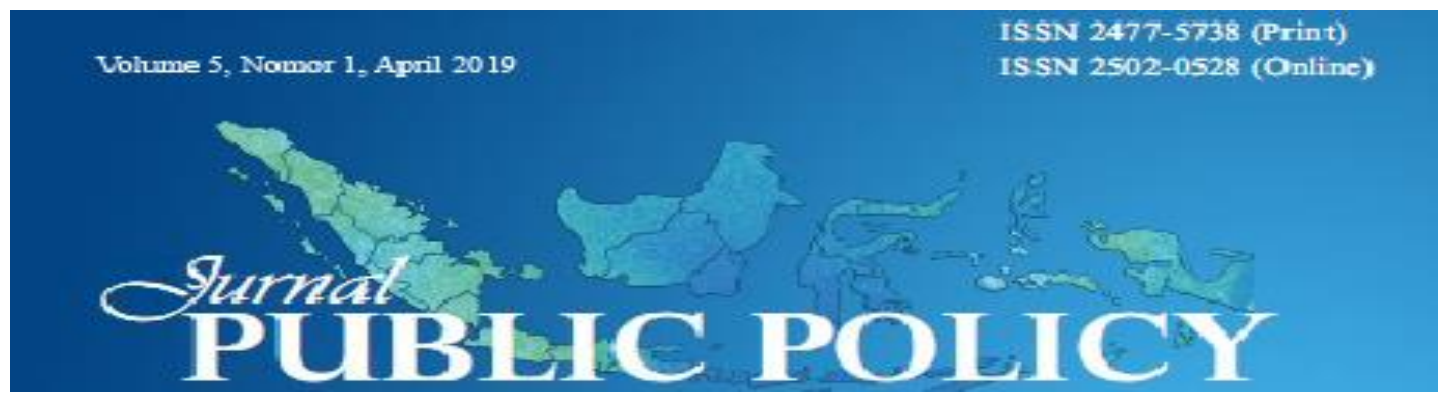

Journal homepage: http//:jurnal.utu.ac.id/jppolicy

\title{
BUDAYA POLITIK WARUNG KOPI WILAYAH PESISIR DI BUMI TEUKU UMAR MENJELANG PEMILU 2019
}

\author{
Egi Saputra $^{1}$, Eko Sanovyanto ${ }^{2}$ Lisantri $^{3}$ Alimas Jonsa ${ }^{4}$ \\ 1,2,3 Mahasiswa Ilmu Administrasi Negara Fakultas Ilmu Sosial dan Ilmu Politik \\ Universitas Teuku Umar \\ egisaputrambo@gmail.com,ekosanovyanto2017@gmail.com, lisantri321@gmail.com \\ ${ }^{4}$ Dosen Ilmu Administrasi Negara Fakultas Ilmu Sosial dan Ilmu Politik \\ Universitas Teuku Umar \\ alimasjonsa@gmail.com
}

\begin{abstract}
This study titled about the political culture of the coffee shop in the coastal areas Teuku Umar before the election in 2019,As for the formulation in the research is how is the political culture of coastal area coffee shops in Teuku Umar Areas Meulaboh West Aceh, and What are the indicators that support politics in the coastal coffee shops that become a political culture in coffee shops.The methodology used in this research is qualitative research methodology, with a descriptive and phenomenological approach, so that in this study the researchers found that coffee shops in the city of Meulaboh had become a political forum utilized by political actors to gain votes in the 2019 general election. This is supported by the coffee shop as a gathering place for the whole community and as a place to discuss and exchange information.
\end{abstract}

Keyword: Culture, Political, and Coffee Shop 


\section{PENDAHULUAN}

Sorensen dan Mc Creary dalam Karya mereka "Institutional Arrangement forManaging Coastal Resources and Environments", kawasan pesisir didefinisikan sebagai "perbatasan atau ruang tempat berubahnya dua lingkungan utama, yaitu laut dan daratan”. Bumi Teuku Umar yang sebagian wilayahnya merupakan daerah wilayah pesisir yang di tinggali oleh masyarakat, seperti pada umumnya masyarakat wilayah pesisir yang mempercayai suatu budaya sebagai suatu pola hidup menyeluruh dan bersifat komplek. Saat ini, berkumpul di warung kopi sudah menjadi salah satu budaya bagi masyarakat wilayah pesisir Bumi Teuku Umar, ini dapat di buktikan dengan adanya warung kopi di sepanjang jalan wilayah pesisir di Bumi Teuku Umar.

Warung kopi di Aceh pada saat ini dapat di katakan sebagai Tempat ketiga setelah rumah dan tempat kerja dalam kehidupan bermasyarakat. Di Aceh, warung kopi merupakan sebuah wadah dan tempat silahturahmi dan pertukaran informasi serta di jadikannya tempat tranformasi politik pada saat ini. Dimana hal tersebut sudah menjadi budaya di bumi serambi mekkah yang di juluki negeri seribu warung kopi. Hal ini tidak lain di karenakan masyarakat Aceh yang pada umumnya menjadikan warung kopi sebagai tempat ketiga yaitu tempat beristirahat, berdiskusi, bertukar informasi, transformasi Politik, atau hanya sekedar menghabiskan waktu.

Penikmat warung kopi di aceh berasal dari semua kalangan baik itu kaum tua maupun muda, pejabat, tokoh masyarakat serta aktivis-aktivis akademisi. Teuku Kemal Fasya dalam Maryoto dan Muhammad (2011) Melihat bahwa pengunjung warung kopi pun tak hanya di dominasi oleh para kaum pria dan lanjut usia, kaum wanita, para remaja juga kerap menghabiskan waktunya di warung kopi. Saat ini, Warung kopi semakin menjadi pilihan yang menarik untuk tempat berkomunikasi, di karenakan warung kopi pada saat ini identik dengan tempat yang nyaman, interior bagus, ruang rapat, fasilitas Free wi-fi, serta televisi layar lebar untuk menonton sepak bola. Sehingga, fungsi warung kopi yang pada dasarnya hanya sekedar tempat meminum kopi kini sudah berubah menjadi lebih luas sebagai tempat berdiskusi, 
bertukar informasi, serta menjadi tempat transformasi politik pada saat-saat Pemilihan umum mendekati.

F.Isjwaramenuturkan politik adalah salah satu perjuangan untuk memperoleh kekuasaan atau sebagai teknik menjalankan kekuasaan-kekuasaan. Untuk mendapatkan sebuah kekuasaan ataupun jabatan dalam pemerintahan baik itu sebagai Eksekutif maupun Legislatif, para calon harus mengikuti pemilihan umum. Sumber Aceh mediart(31 Desember 2018).

Tahun 2019 merupakan tahun pesta demokrasi di indonesia, dimana pemilihan Presiden, Dewan Perwakilan Rakyat (DPR) Dewan Perwakilan Daerah (DPD) di laksanakan secara serentak mulai dari level kabupaten Kota, wilayah propinsi sampai ketingkat pusat, serta menjadi momentum bagi masyarakat untuk menentukan pilihannya. Di Aceh, Warung kopi memiliki dampak yang besar terhadap keputusan masyarakat dalam memutuskan pilihannya, karena bagi masyarakat Aceh, warung kopi tak hanya sekedar tempat untuk meminum kopi, namun sudah menjadi tradisi di Aceh warung kopi menjadi wadah dan tempat pertukaran informasi, berdiskusi, hingga berkampanye politik sekalipun. Di sebabkan oleh alasan di atas, warung kopi dapat menentukan pilihan masyarakat dalam pemilihan umum di karenakan berbagai informasi yang di dapat serta berbagai kampanye politik yang di dengarkan di warung kopi.

\section{KERANGKA KONSEP Konsep Teori}

Menurut penelitian yang di lakukan oleh M. Nur Alamsyah pada Tahun 2010 dengan judul Budaya Politik Dan Iklim Demokrasi Di Indonesia dengan hasil penelitian masyarakat Indonesia dan elitnya pada penyelenggaraan kekuasaan sering memakai kekuasaannya tanpa control atau kendali akibatnya, aturan permainan dan hukum kerap tidak dijadikan koridor dalam pelaksanaan kenegaraan dan kehidupan kemasyarakatan. Kepercayaan (trust) masyarakat menjadi sangat lemah terhadap hukum atau aturan, budaya politik. Hal tersebut melemahkan disiplin sosial yang telah memiliki cikal bakal dan catatan sejarah dalam masyarakat Indonesia secara 
luas. Pada setiap aktifitas dalam setiap proses politik masyarakat, akan senantiasa terjadi dalam lingkup budaya, yang dapat digambarkan bahwa pada jangka waktu tertentu, akan selalu terjadi proses dialektika timbal balik antara kehidupan politik di satu pihak dengan sistem nilai budaya masyarakat pada pihak lain, yang kemudian membentuk sebuah kepercayaan yang luas dan dijadikan sebagai sebuah komitmen meskipun hadir sebagai consensus yang tidak tercatat, tetapi dilakukan dan mengalami perbaikan secara kualitatif setiap saat. Keberhasilan penguatan budaya politik pada setiap bangsa dapat tercapai melalui proses sosialisasi politik. Proses inilah yang mewariskan berbagai nilai politik dari satu generasi ke generasi berikutnya.

Penelitian kedua yang di lakukan oleh Prijantono Astjario Dan Harkinz Prabowo pada tahun 2005 dengan judul Penelitian Lingkungan Pantai Wilayah Pesisir Kabupaten Cirebon, Jawa Barat dengan hasil penelitian Sumber daya alam yang tersedia saat ini mengalami penurunan mengingat adanya peningkatan pembangunan yang pesat serta populasi manusia yang terus meningkat. Maka tidak menutup kemungkinan bahwa sumber daya laut akan menjadi primadona sebagai penunjang perekonomian ke depan. Wilayah pesisir dan laut tampaknya akan dijadikan kawasan yang diprioritaskan untuk pengembangan industri, agrobisnis, agroindustri, pemukiman, pariwisata, transportasi dan pelabuhan. Akan tetapi wilayah ini masih menyimpan beragam permasalahan yang menyebabkan pengembangan dan pengelolaannya menjadi tidak maksimal. Menurunnya baku mutu air laut karena tingkat kekeruhan yang tinggi, tercemar limbah padat maupun cair, intrusi air laut, abrasi, akerasi, pendangkalan, banjir, dan kekeringan merupakan beberapa butir permasalahan yang kita jumpai di wilayah pesisir dan laut. Tidak kalah pentingnya adalah perilaku manusia yang telah merambah tumbuhan bakau dan merubah fungsi hutan rawa menjadi tambak.

\section{Wilayah Pesisir}

Menurut Sorensen Dan Mccreary Dalam karya mereka "Institutional Arrangementfor Managing Coastal Resources and Environments", kawasan pesisir 
didefinisikan sebagai "perbatasan atau ruang tempat berubahnya dua lingkungan utama, yaitu lautdan daratan”

Pengertian kedua menurut Bengen (2000:3) "Wilayah daratan dan wilayah laut yang bertemu di garis pantai di mana wilayah daratan mencakup daerah yang tergenang atau tidak tergenang air yang dipengaruhi oleh proses-proses laut seperti pasang surut, angin laut, dan intrusi air laut. Sedangkan wilayah laut mencakup perairan yang dipengaruhi oleh proses-proses alami daratan seperti sedimentasi dan aliran air tawar ke laut serta perairan yang dipengaruhi oleh kegiatan manusia di darat".

Jadi, menurut paparan di atas, maka dapat di tarik kesimpulan bahwa wilayah pesisir merupakan suatu wilayah tempat bertemunya garis pantai dan daratan yang mempunyai kekayaan alam baik yang terdapat di laut maupun di daratannya.

\section{Pemilihan Umum (Pemilu)}

Menurut Ali Moertopo "Pada hakekatnya, pemilu adalah sarana yang tersedia bagi rakyat untuk menjalanakan kedaulatannya sesuai dengan azas yang bermaktub dalam Pembukaan UUD 1945. Pemilu itu sendiri pada dasarnya adalah suatu Lembaga Demokrasi yang memilih anggota-anggota perwakilan rakyat dalam MPR, DPR, DPRD, yang pada gilirannya bertugas untuk bersama-sama dengan pemerintah, menetapkan politik dan jalannya pemerintahan negara”.

Devinisi kedua Menurut Ramlan (1992:181) Pemilu diartikan sebagai mekanisme penyeleksian dan pendelegasian atau penyerahan kedaulatan kepada orang atau partai yang dipercayai.

Jadi, menurut paparan di atas, maka dapat di tarik kesimpulan bahwa Pemilu merupakan suatu sistem dimana rakyat dapat menentukan pilihannya terhadap wakil rakyat melalui pemilihan langsung dan dapat mendongkrak terwujudnya nilai-nilai demokrasi yang berkembang di kehidupan masyarakat. Sehingga masyarakat dapat menyuarakan haknya sebagai warga negara dalam pemilihan langsung melalui pemilihan umum. 


\section{Budaya Politik}

Gabriel A. Almond Dan G.Bingham Powell, Jr. Menuturkan bahwa budaya politik adalah sikap, keyakinan, nilai danketerampilan yang berlaku bagi seluruh populasi, jugakecenderungan dan pola-pola khusus yang terdapat pada bagian-bagian tertentu dari populasi.

Rusadi Kantaprawira (Kantaprawira, 1999:26) Budaya politik merupakan persepsi manusia, pola sikapnya terhadap berbagai masalah politik dan peristiwa politik terbawa pula ke dalam pembentukan struktur dan proses kegiatan politik masyarakat maupun pemerintahan, karena sistem politik itu sendiri adalah interrelasi antara manusia yang menyangkut soal kekuasaan, aturan dan wewenang.

Jadi menurut paparan di atas, dapat di tarik kesimpulan bahwa Budaya politik merupakan suatu persepsi dan kebiasaan yang di lakukan oleh masyarakat terhadap berbagai masalah politik dan di percayai serta di lakukan oleh populasi masyarakat di suatu daerah yang sama.

\section{Teori Budaya Politik}

Penelitian ini menggunakan Teori Gabriel A. Almond Dan G.Bingham Powell, Jr. Menurutnya Budaya politik mencakup beberapa aspek :Sikap, Keyakinan, Nilai dan keterampilan, Adanya pola khusus.

\section{METODE PENELITIAN}

Tempat dan Waktu Penelitian mengenai Budaya Politik Warung kopi Wilayah pesisir di Bumi Teuku Umar ini dilakukan di Kabupaten Aceh Barat dengan durasi waktu kurang lebih 3 bulan.

Metode Penelitian yang digunakan pada penelitian ini adalah metode kualitatif dengan pendekatan deskriptif dan fenomenologis. Teori yang digunakan menggunakan teori Gabriel A Almond.

Teknik Penentuan Informan dalam penelitian dengan menentukan informasi kunci yaitu masyarakat di wilayah pesisir khususnya penikmat kopi. Informan yang dipilih 
dalam penilaian ini adalah: Akademisi, Para remaja, Mahasiswa, Masyarakat, Pejabat partai.

Teknik Pengumpulan Data dilakukan dengan teknik observasi, wawancara dan dokumentasi. Observasi digunakan untuk mengetahui indikator-indikator yang menyebabkan warung kopi menjadi sarana perpolitikan. Peneliti melakukan penelitian dengan pedoman observasi yang telah ditetapkan (Arikunto, 2006). Metode wawancara digunakan peneliti untuk mendapatkan informasi-informasi mengenai warung kopi yang menjadi sarana perpolitikan Dokumentasi merupakan suatu teknik pengumpulan data dengan menghimpun dan menganalisis dokumen-dokumen baik dokumen tertulis, gambar maupun dokumen elektronik. Dokumen-dokumen yang dihimpun dipilih sesuai dengan tujuan dan fokus masalah (Sukmadinata, 2005).

\section{Teknik Analisis Data dan Uji Keabsahan Data}

Penelitian ini adalah penelitian deskriptif, dengan lebih banyak bersifat uraian dari hasil wawancara dan studi dokumentasi. Data yang telah diperoleh akan dianalisis secara kualitatif serta diuraikan dalam bentuk deskriptif.

Menurut Patton (Moleong, 2002) analisis data adalah "proses mengatur urutan data, mengorganisasikan ke dalam suatu pola, kategori dan uraian dasar". Definisi tersebut memberikan gambaran tentang betapa pentingnya kedudukan analisis data dilihat dari segi tujuan penelitian. Prinsip pokok penelitian kualitatif adalah menemukan teori dari data.

Teknik analisis data yang digunakan dalam penelitian ini adalah menggunakan langkah-langkah seperti yang dikemukakan oleh Burhan Bungin (2001), yaitu sebagai berikut:

Pengumpulan Data (Data Collection) Pengumpulan data merupakan bagian integral dari kegiatan analisis data. Kegiatan pengumpulan data pada penelitian ini adalah dengan menggunakan wawancara dan studi dokumentasi. 
Reduksi Data (Data Reduction) Reduksi dilakukan sejak pengumpulan data dimulai dengan membuat ringkasan, mengkode, menelusur tema, membuat gugusgugus, menulis memo dan sebagainya dengan maksud menyisihkan data/informasi yang tidak relevan.

Display Data Display data adalah pendeskripsian sekumpulan informasi tersusun yang memberikan kemungkinan adanya penarikan kesimpulan dan pengambilan tindakan. Penyajian data kualitatif disajikan dalam bentuk teks naratif. Penyajiannya juga dapat berbentuk matrik, diagram, tabel dan bagan.

Verifikasi dan Penegasan Kesimpulan (Conclution Drawing and Verification) Merupakan kegiatan akhir dari analisis data. Penarikan kesimpulan berupa kegiatan interpretasi, yaitu menemukan makna data yang telah disajikan.

\section{HASIL DAN PEMBAHASAN}

Meulaboh, Aceh Barat sebuah kota dimana warung kopi menjadi tempat paling di gemari oleh seluruh lapisan masyarakat, baik yang tua, muda, pejabat, hingga buruh sekalipun menjadikan warung kopi sebagai tempat ketiga yang paling sering di kunjungi selain rumah dan tempat kerja. Dari hasil penelitian peneliti di lapangan, ada beberapa faktor yang mempengaruhi warung kopi menjadi tempat yang sangat di gemari untuk di kunjungi di Meulaboh, yaitu Free Wi-Fi yang di sediakan di warung warung kopi, Tempat yang nyaman, dan rasa kopi yang nikmat. Dari faktor di atas, warung kopi menjelma menjadi sebuah tempat perkumpulan masyarakat di kota Meulaboh. Banyak hal yang di lakukan di warung kopi, mulai dari kalangan muda yang memanfaatkan warung kopi sebagai tempat untuk berdiskusi, bermain game, atau bahkan hanya sekedar bertemu sapa. Tak ketinggalan dari kalangan tua yang juga memanfaatkan warung kopi sebagai tempat bertukar informasi, atau juga hanya sekedar menikmati segelas kopi.

Menjelang Pemilu, para aktor politik memanfaatkan peluang sekecil apapun untuk meraup suara pada saat Pemilu di laksanakan. Tak terkecuali warung kopi yang menjadi tempat perkumpulan masyarakat meulaboh menjadi sasaran utama dari para 
aktor-aktor politik untuk berkampanye, baik itu di lakukan secara terbuka maupun secara tertutup person to person. Dari hasil kunjungan lapangan peneliti, warung kopi sebagai tempat yang paling ramai dan paling sering di kunjungi oleh masyarakat menjadi alasan utama para aktor politik meraup suara di warung kopi. Tak terelakkan, saat ini warung kopi sudah menjadi sebuah budaya politik di kota Meulaboh.

Pengunjung warung kopi yang biasanya mengunjungi warung kopi hanya untuk tujuan-tujuan yang biasanya, menjelang Pemilu 2019 ini warung kopi menjelma menjadi sebuah wadah perpolitikan antara aktor politik dan masyarakat. Antusiasme yang di tunjukkan oleh masyarakat dalam Pemilu kali ini pun menjadi salah satu faktor yang menjadikan Warung kopi sebagai sebuah budaya perpolitikan di wilayah pesisir kota Meulaboh.

Warung kopi di kota meulaboh sebagai sebuah budaya perpolitikan di karenakan adanya indikator-indikator yang mendorong hal tersebut. Adapun indikator-indikator yang menyebabkan warung kopi menjadi sebuah budaya perpolitikan di meulaboh adalah warung kopi sebagai sarana berdiskusi bagi seluruh kalangan masyarakat, sebagai tempat perkumpulan bagi kalangan muda, serta menjadi tempat peristirahatan bagi para pegawai di saaat jam istirahat. Indikatorindikator inilah yang mendorong warung kopi sebagai tempat yang paling di manfaatkan oleh para aktor politik untuk berkampanye demi meraup suara, sehingga warung kopi berubah menjelma sebuah Budaya Politik di wilayah pesisir kota meulaboh menjelang Pemilu di laksanakan.

Sarana Berdiskusi, dari hasil penelitian yang peneliti lakukan, salah satu indikator warung kopi di Meulaboh menjadi sebuah Budaya Politik adalah warung kopi sebagai sarana berdiskusi baga seluruh kalangan masyarakat. Dari kaum muda yang memanfaatkan warung kopi untuk tempat mendiskusikan masalah-masalah organisasi serta mendiskusikan tugas perkuliahan atau tugas sekolah, kaum tua yang memanfaatkan warung kopi sebagai sarana bertukar informasi dengan sesamanya, hingga para kaum elit yang memanfaatkan warung kopi untuk mendiskusikan masalah-masalah bisnis dan pekerjaannya.dari hasil wawancara yang peneliti 
lakukan, kegiatan berdiskusi di warung kopi sudah menjadi sebuah rutinitas bagi kalangan mahasiswa, kaum elit, hingga masyarakat biasa. Hal inilah yang mendorong para aktor politik untuk melakukan kampanye di warung kopi menjelang Pemilu 2019 ini demi meraup suara di Pemilihan Umum yang akan di laksanakan pada 17 April. Sarana Perkumpulan, selain sarana berdiskusi warung kopi merupakan tempat perkumpulan khususnya bagi para kaum muda. Bermain game adalah tujuan utama, dengan di sediakannya jaringan Wi-Fi semakin menarik minat kaum muda untuk memanfaatkan warung kopi sebagai sarana perkumpulan untuk bermain game. Pemain game yang biasanya di sebut gamers dapat menghabiskan waktu hingga 8 jam lebih dalam sehari hanya untuk bermain game di warung kopi. Hal inilah yang di manfaatkan oleh para aktor politik untuk melakukan kampanye pada kaum muda, melalui pendekatan-pendekatan yang berbeda, mulai dari berkecimpung dengan para gamers sendiri, hingga mensponsori ajang turnamen E-Sport yang bertujuan untuk meningkatkan elektabilitas pada para kaum muda.Tempat Peristirahatan, mahasiswa, pegawai, hingga pejabat sekalipun memanfaatkan warung kopi sebagai tempat peristirahatan yang rutin di kala jam istirahat kerja, di karenakan warung kopi yang mudah di jangkau, serta faktor kenyamanan yang di berikan warung kopi menjadi sebab warung kopi sebagai tempat beristirahat.

Warung kopi dapat di katakan sebagai sebuah budaya politik di Meulaboh di karenakan masyarakat setempat serta para aktor politik memiliki rutinitas dan pola yang dapat di gambarkan dalam mengunjungi warung kopi, serta keyakinan dari para aktor politik yang meyakini bahwa warung kopi sebagai sasaran empuk untuk meraup suara dalam Pemilu.

\section{SIMPULAN}

Warung kopi sebagai tempat yang paling di gemari untuk di kunjungi di kota Meulaboh, ada beberapa faktor yang mempengaruhi warung kopi menjadi tempat yang sangat di gemari untuk di kunjungi di Meulaboh, yaitu Free Wi-Fi yang di sediakan di warung warung kopi, Tempat yang nyaman, dan rasa kopi yang nikmat. 
Hal inilah yang menjadikan warung kopi sebagai sarana berdiskusi, tempat perkumpulan, serta tempat beristirahat bagi para mahasiswa, karyawan, pejabat, hingga kaum elit sekalipun di saat waktu istirahat.

Menjelang Pemilihan Umum 2019 di laksanakan, warung kopi menjadi tempat yang paling sering di kunjungi oleh masyarakat menjadi sasaran utama para aktor politik untuk berkampanye demi meraup suara dala pemilihan umum. Hal ini di karenakan masyarakat mempunyai rutinitas dan pola yang jelas dalam mengunjungi warung kopi, serta keyakinan dari aktor politik tersendiri dalam memanfaatkan warung kopi sebagai sarana untuk menaikkan elektabilitasnya. Berkampanye secara tertutup dengan cara berbaur langsung dengan masyarakat, berdiskusi, hingga mensponsori turnamen E-Sport yang biasanya di lakukan di warung kopi, merupakan cara-cara dari aktor politik untuk meningkatkan elektabilitas untuk meraup suara menjelang pemilihan umum 2019 di kota Meulaboh.

\section{REFERENSI}

Alamsyah m. Nur. 2001. Budaya politik dan iklim demokrasi Indonesia. Universitas Sumatra Utara

Novitayani. 2014. Warung kopi sebagai sarana komunikasi dan bertukar informasi bagi profesi wartawan. Universitas Sumatra Utara

Zakky. 2018. Pengertian politik menurut ahli dan secara umum. Di akses pada 30 desember 2018.www.zonareferensi.com/pengertian-politik/

Moleong, Lexy. 2002. Metodologi Penelitian Kualitatif. Bandung: PT. remaja Rosdakarya.

Sukmadinata. 2005. Metode Penelitian. Bandung: Remaja Rosdakarya.

Burhan Bungin. 2001. Metode Penelitian Kualitatif. Jakarta: PT Rajagrafindo Persada Iskandar, tu-ngang. 2015. Budaya politik dan politik budaya di Aceh. Di akses pada 30 desember 2018. http://www.acehmediart.com/2015/12/budaya-politik-danpolitik-budaya-di.html 